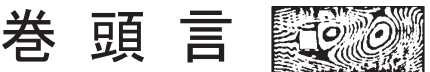

\section{風工学と気象学の連携 \\ Cooperation of Wind Engineering and Meteorology}

藤部文昭 ${ }^{*}$

Fumiaki FUJIBE

風工学会へ入会してから 20 年になりますが, どうも気 象学の影が薄いことを感じます。

筆者の大学院時代の研究テーマは風でした。しかし, 風と言っても晴れた日に吹く海陸風や山谷風であり, 風 工学との接点は弱いと思っていました。また, 伊勢湾台 風や第 2 室戸台風以降, 強い台風の来襲が少なかったこ ともあり, 当時の気象研究者の興味は主として豪雨や豪 雪に向けられていました。気象学会の年次大会でも, 強 風に関寸る研究は何となく肩身が狭く, 故・光田寧先生 (京大防災研) のグループが孤軍奮闘しているという感 じでした。それでも，1990 年代になると台風 9119 などを きっかけにして状況が少し変わりました。1970８0 年代 に比べて強い台風の来襲が増え, 強風についての研究の 必要性が見直されてきたように思います。筆者も台風な どの強風に手を出すようになり，学会誌を読みたくて風 工学会へ入れて頂いたという次第です。

その後は気象の分野でも竜巻などの突風現象に対する 関心が高まってきました。日本の竜巻が増えたという証 拠はなく, 今でも被害件数は竜巻より台風のほうが多い のですが，突然ゴーッと襲ってくる竜巻の卨威に対する 社会の関心は大きいものがあります。また，台風の予報 精度が向上してきたのに対し, 竜巻の予測はまだ難しく, 研究の動機づけが大きいという事情もあります。さらに, 数值気象モデルの空間分解能が高まり, 竜巻のスケール にも手が届くようになったことや，レーダーが高度化さ
れて高品質の観測データが得られるようになったことも， 研究をもり立てる要素になりました。台風についても, 衛星などリモートセンシングのデータが充実して研究の 活性化をもたらし，また，地球温暖化の進展で「スーパ 一台風」が来るようになるという話も出てきて, 研究の 幅が広がってきたように思えます。

台風 9119 や台風 9807 の後には, 山林の被害を現地一 見に行きました。そこで強い印象を受けたのは，被害の 局在性でした。台風 9807 は室生寺の五重塔の損壊が話題 になりましたが，現場へ行ってみると被害があったのは 塔の付近だけであり, 寺が位置する山の他の場所はほぼ 無傷でした。室生寺以外の場所も同様であり, 山肌のう ちのある部分だけ，爆撃でも受けたように木が倒れてい ました。台風 9807 は果樹の被害も大きかったのですが, これも山林と同じで,「隣の畑は無事なのに，ウチの木は 倒れちやった，なぜなんだ!」という類のことがあった ようです。そして，「なぜなんだ」と聞かれても答えるこ とができないことに，気象研究者としてもどかしさを感 じました（そんな細かいスケールのことは気象庁の業務 ではない…言えば, 公式見解としては正しいのですが, 伝統的な気象学では太刀打ちできないことに無力感を持 ちました)。

近年は, 気候変動への関心が高まるにつれ，気象デー タの品質の重要性が認識されるようになりました。長期 的な気候変動を正しく捉えるためには，時間的に均質な 
データが必要です。しかし, 風速の観測はまわりの建物 や樹木に影響されるほか, 風速計の特性にも依存します。 また, 気温や降水量の観測にも測器の周囲の風が影響し, 露場の風通しの大小に応じて観測值にバイアスが生じま す。東京大手町にある気象庁の旧露場の場合，その端に ある樹木に囲まれた場所では露場中央に比べて風速が 3 分の 1 にとどまり，夏の日中には気温が平均 $0.5^{\circ} \mathrm{C}$ 高いこ とが分かりました。おずか $20 \mathrm{~m}$ ほどの距離で $0.5^{\circ} \mathrm{C}$ 気温 差ができるのは予想外であり, 微気象の奥の深さを知り ました。

このように, 気象学の研究対象が多様化するにつれ, 風工学で扱われてきた瞬発的な強風や, 建物など地物周 辺の気流も取り上げられるようになりました。それなら， もっと気象の研究者に風工学会へ入ってほしいのですが, 残念ながらそうはなっていません。むしろ, 風工学会に 入っていた古参の気象研究者が引退した後, 若い会員が 少なくなっています。

なぜ, そうなのでしょうか。1つ考えられるのは, 㛜し い成果主義と任期つき雇用のもと, 若手の研究者にとっ て国内の学会に関わる余裕がなくなってきたことです。 優秀な研究者はプロジェクト研究で多忙を極めています。 競争的資金を取れば, 海外の学会や研究集会一行けるし, インパクト・ファクターの高い国際誌にも投稿できます。
また，そうでもして成果を積み上げないと，研究者とし て生き残れないという危機感があります。

実際，学会員の減少は筆者の古巣である気象学会でも 問題になっています。機関誌のオープンアクセス化がそ の一因ではないかと言われますが，どうもそれだけでは なさそうです。国内の若手研究者の論文投稿が少ない （これは筆者の主観ですが）ことを考えると，国内学会 の有り難みが薄れてきているのかも知れません。

もう 1 つの問題は「工」の字です。気象の研究者は風 工学というと, 構造物の耐風設計のような工学技術を思 い浮かべ，自身の研究分野とは関係がないと思います。 しかし，これには「食べず嫌い」という面があるでしょ う。例えば，過去の風速データの時間的均質性について の検討は，気象分野よりも風工学会のほうが進んでいま す。また，近年は気象分野で極值統計一の関心が高まっ てきましたが，風工学会誌には以前からこのテーマの興 味深い論文が載っています。熱中症をもたらす風環境も 風工学会誌で扱われています。風工学会という名前を変 えれば気象研究者の入会が増えるのでは…というのは悪 い元談ですが（済みません）, 風工学会の実情をPRする ことによって, 気象研究者を取り込んでいけるかも知れ ません。風工学と気象学の連携を深め, 学会の活性化を 図れるよう気を配っていきたいと思うところです。 